\title{
The Level of Involvement with the Olimpic Games and its Influence in Sport Sponsorship.
}

\author{
Soledad Zapata ${ }^{1}$ \& Laura Martínez ${ }^{2}$ \\ ${ }^{1}$ Universidad Politécnica de Cartagena. Murcia. Spain \\ ${ }^{2}$ Universidad Politécnica de Cartagena. Murcia. Spain \\ Correspondence: Zapata Agüera, Soledad. Universidad Politécnica de Cartagena. Real , 3, 30201. Murcia. Spain.
}

Received: May 2, 2018 Accepted: May 22, 2018 Online Published: July 26, 2018

doi:10.5539/res.v10n3p94 URL: https://doi.org/10.5539/res.v10n3p94

\begin{abstract}
In this research, intend to demonstrate the influence of the consumer involvement in a finer brand purchase intent of the sponsor, and generate an effect on the consumers "goodwill" towards the sponsor and also to perceive a greater fit between sponsor and event, and finally cause the consumer better exposure in the event. This was chosen the Rio 2016 Olympic Games. In this study, different analyses have been conducted to verify reliability and factorial scales of charges. As well as analyses to contrast the hypotheses: ANOVAS and structural equations using the SmartPLS program (is a software with graphical user interface for variance-based structural equation modeling (SEM) using the partial least squares (PLS) path modeling method ${ }^{1}$ ), to check the fit for the model. It is interesting to highlight the contribution to this research, because if organizations look for sporting events with a public involved with them. Consequently will get a bigger intention to purchase the sponsor's brand, a finer perception of both the goodwill and the fit between the event and the sponsor, and finally a larger exposure in the event and accordingly, to the promotions made by sponsor brands.
\end{abstract}

Keywords: Exposure, fit event-sponsor, goodwill, involvement level, purchase intention, structural equations and sponsorship

\section{Code of Journal of Economic Literature: M31 Marketing}

\section{Introduction}

For Gómez (2017) sports sponsorship is like a "contract by which a company or institution allocates economic resources (or benefits in kind) to an activity of a sporting nature or to a team or individual athlete, the brand sponsor or its messages disseminated throughout the competition in question, looking at some elements necessary for its realization through the media. Examples range from overprints on the T-shirts to multi-million-dollar contracts Nike or Adidas sponsorship with some athletes"(p. 179).

Therefore "a sporting event viewer receives stimuli not only the game, but a whole battery of actions that complement each other, the pre-show, which eat, drink, etc. (...)" make up the total perception of the event and the final valuation of the same influence (Cubillo \& Matterhorn, 2008, p. $153^{2}$ ). Therefore, the sponsorship as a tool in the service of marketing is so important since this influences the way in an event is perceived it.

In this context, it can consider the involvement as one of the most important variables to explain and predict the behavior of the consumer (Evrard and Aurier, 1996), for their influence on the processing on the data stored in memory (Maheswaran and Sternthal, 1990) and the external information searches for a pre-order (Chaudhuri, 2000). This corroborates the investigations realized in this field (Stipp \& Schiavione, 1996; Pham, 1992; Lascu, Giese, Toolan, Guehring \& Mercer, 1995; D'Astous \& Bitz, 1995; Speed \& Thompson, 2000; Meenaghan, 2001; Gwinner \& Swanson, 2003; Grohs, Wagner. \& Vsetecka, 2004; Greenwood, Kanters \& Casper, 2006; Olson, 2010; Alexandris \& Tsioutsou, 2012; Grohs \& Reisinger, 2014; Alonso-Dos-Santos, Vveinhardt, Ferran \& Montoro-Rios, 2016).

While the results of the variable level of involvement have been widely analyzed throughout the literature, there are scarce investigations that have tried to examine the effect of involvement in the event, specifically on the results of the

\footnotetext{
1 Wong, K. K. K. (2013). Partial least squares structural equation modeling (PLS-SEM) techniques using SmartPLS. Marketing Bulletin, 24(1), 1-32.

2 Cubillo Pinilla. J. M. y Cerviño Fernández, J. (coordinadores) (2008) Marketing sectorial. Madrid. ESIC Editorial.
} 
sponsorship. For this reason, and in order contribute scientifically in this line, propose to collect in a single research the most important effects referred to in previous investigations such as the intent to purchase, the fit between the event-sponsor, the perception of "goodwill" and the exposure in the event and check through the Partial Least Squares Structural Equation molding that the proposed representation is a good fit. Only taking into account this variable as an element to discern that sporting event to choose, will obtain a large sponsorship effectiveness, being important to the organizations.

\section{Research in Sponsorship: Literature Review and Hypothesis Approach}

The first to use the term "involvement" were Sheriff and Cantril (1947) relating this variable to the self-concept and ego, and its influence on attitudes extend beyond the study on the consumer behavior.

In general terms, the involvement has to do with the importance that an individual gives an object, in particular (Greenwald \& Leavitt, 1984). In this sense, according to Zaichowsky (1985, p. 342), the involvement is defined as "the personal importance perceived as an object, specifically, based on their needs, values and interests." This same approach is the one signed in the field of sports marketing by authors such as Bennett, Ferreira, Lee, \& Polite (2009); Ko, Kim, Kim \& Lee (2010); Beaton, Funk, Ridinger \& Jordan (2011); Hur, Ko \& Claussen (2012) or Stevens and Rosenberger (2012).

Lardinoit and Derbaix (2001, p.170) defined it as "a kind of genuine enthusiasm, a strong and solid interest, which comes to give importance to an object, activity, or person for the individual." For Havitz and Dimanche (1997, p. 246) considered the involvement as "an unobservable state of motivation, excitement or interest in recreation or a product-related activity."

Moreover, for Antil (1984), explained that the involvement was the level where feels the personal importance evoked by a stimulus. In terms of social psychology, can be defined as "a state of motivation, influenced by the perception as an object (e.g., action sports) person importance based on inherent needs, values, and interests"(...)"and its history" are the characteristics of the person, stimulus/object (e.g., action sports), and the situation" (Day, Royne \& Camacho, 1995, p. 70); furthermore, supported by Bloch and Brian, (1983); Zaichkowsky (1985); Celsi and Olson (1988); Havitz and Howard (1995); Iwasaki and Havitz (1998); Funk, Redinger, \& Moorman (2004); Huang (2006).

When this excitement or interest refers to a motivational state, manifests itself in the relationship to the product or with the act of purchase, which will be based upon the system of values that the individual has (Laurent \& Kapferer, 1985; Mittal, 1989; Day et al., 1995). Therefore, involvement includes an assessment of the importance of the stimulus for the consumer but adds a certain behavior as a result of the same, i.e. involvement motivates to action (Pérez, 2006).

Similarly, when consumers are involved to a greater degree with an event, information processing does centrally (Droge, 1989). Thus, in direct comparisons, it has a positive influence, since has been produced by the central processing of information, and consequently, there is no interference due to the motivations. This situation has been more likely arisen when cognitive involvement is higher (a condition that increases the value of the comparative information to the consumer) and there is a high emotional involvement. In addition, persons processed the message differently depending on, among other variables, like an individual involvement in the message, the product or the purchase decision. In short, singular involvement is the biggest determinant of the probability that the consumer processes the message (Funk, Ridinger, \& Moorman, 2004; Grohs \& Reisinger, 2014).

Bennett et al. (2009) distinguished three types of involvement: durable, situational, and behavioral (Day et al., 1995). On the lasting involvement, it occurs when an individual buys the equipment and costumes associated with the sport of interest and in addition also consumes the sport through the media. Therefore, an individual who participates in a sport will be more likely to devote more time to the same consumption, attending sporting events and watching television retransmission (Kahle, Kambara, \& Rose, 1996; Laverie \& Arnett, 2000; Donovan, Garlson \& Zimmerman, 2005). Situational involvement, is one where the individual experiences a temporary involvement (Rotchschild, 1984); in this case, the involvement is caused by the situation which is in the consumer, as well as be influenced both by the physical context and social (Peter \& Olson, 1987). Finally, the participation of behavior refers to the time and/or intensity of effort spent on the pursuit of an activity, in particular (Stone, 1984).

In addition, throughout the literature, there are several authors, which have analyzed the different levels or degrees of involvement. Make this differentiation to varying degrees in sport is important, because according to Gwinner and Swanson (2003), the level of involvement of the consumer with an activity, person or patronized team, influences the effectiveness of the sponsorship. Thus, the study Meenaghan (2001) believes that individuals don't have the same level of involvement and distinguish three levels: 1) slightly involved; (2) moderately involved; and (3) highly involved. Meenaghan (2001) performs this classification to segment the population that displays an event and does so on the basis that this is not homogeneous in terms of degree of interest or participation.

In this line, Dees, Bennett \& Villegas (2008). For whom the fan involvement is an integral construction, which means that in assessing the effectiveness of sponsorship, should keep in mind that there are different emotional levels of engagement 
by the consumer with the sponsored event. Depending on how involved the consumer with the favorite sport or type of event, could set distinctive relationships with the sponsorship (Quester \& Thompson, 2001).

This fact is supported by Lascu et al. (1995), argue that high levels of involvement could affect positively the consumer motivation to process the information received regarding an activity, team or athlete sponsored (Greenwald \& Leavitt, 1984; Celsi \& Olson, 1988). Therefore, a great motivation in the processing of the information, would produce a big efficiency of the sponsorship.

Based on the theory of social identity, Gwinner and Swanson (2003), to expand the scope of research in sponsorship on the identification of the sponsor, coming to the conclusion that those people who are fans of a sport and have a high level of identification with a team, present as well as a higher level of recognition of sponsorship and more favorable attitudes than those who do not have that high level of identification. Under the same argumentation, Grohs and Reisinger (2014) considered that the fan involvement develops a more positive attitude towards the sponsor brand and supported moreover by Alexandris, Tsaousi \& James (2007). High levels of individual's involvement imply a greater acquisition of information and participation in the word of mouth.

Hence, when the consumer attends a sporting event, for Bennet et al. (2009), means that consumers who attend a sporting event are more involved with that particular sport, and this leads them to attend more events related to it. For this reason, the sponsors must rely on that those individuals most involved with sport will be more likely to attend sporting events. It should not be forgotten, as argued Bennett, Ferreira, Tsuji, Siders, \& Cianfrone (2006), involvement in sport as a factor with a significant influence on the use of the mark, it is also possible that it influences the behavior as a spectator, increasing exposure and as a result, is progressively exposed to promotions from sponsor brand.

For Küster, Vila \& Aldás (2009) when high levels of assistance are given, greater exposure to the event, and this exhibition is related to the event image. The event image, according to Keller (1993), are the perceptions of an event, which are a reflection of the associations in the consumer's memory. Küster et al. (2009) highlights that non-symbolic and emotional perceptions that facing the event is transferred to the sponsor brand. Therefore, the image perception of the event for the consumer is so important.

Similarly, studies like those of Dees et al. (2008) or Yong Jae, Kyoungtae, Cathryn \& Tae Hee (2008) and Gilaninia and Abbaszadeh (2011), shows how the sport fan involvement directly affects awareness, image and purchase intent of the sponsor brand. It can be assumed that to higher levels of knowledge and image, and a higher level of purchase intent could be. In addition, the corporate image is directly influenced by the sponsor knowledge (Gilaninia \& Abbaszadeh, 2011). According to Yong Jae et al. (2008), purchase intent can be a great indicator of the sponsorship effectiveness, especially when a sponsor is involved in sporting events often are aimed at fans of a sport, leading them who share a unique identity.

Additionally, many studies, it has been suggested that involvement, as a construct, is crucial when considering the loyalty to the brand, purchase or consumption of this (Bloom, 1981; Homer \& Kahle, 1988; Ashforth \& Mael, 1989; Branscombe \& Wann, 1991; Schiffman \& Kanuk, 1991; Lovelock, Patterson \& Walker, 1998; Miloch \& Lambrecht, 2006; Yong Jae et al., 2008; Filo, Funk, \& O’Brien, 2010).

The level of involvement also affects other variables, Meenaghan (2001) suggests that the intensity of the perception of goodwill is moderated by the consumer involvement with the sponsored activity, since the amateur will perceives more goodwill to the sponsor because believes that the sponsorship benefits the athlete, the team or the favorite event. Dees, Bennett \& Ferreria (2010) defines the goodwill as the transmission from the sporting event to the sponsor of the favorable attitude the affiliation and support for such activity by the consumer-generated. In this sense, Dees et al. (2008) found a positive relationship between involvement and goodwill. Also, Grohs and Reisinger (2014) showed that consumers highly involved in the activity sponsored expressed a greater willingness to the sponsors.

Yong Jae et al. (2008) and Filo et al. (2010), established that consumers with a high level in the same way, Smith and Stewart (2015) demonstrate that the level of involvement in the response to the sponsorship is also important since, it is guided by the involvement in the activity sponsored. So, consumers who have higher levels of involvement, show one knowledge on the sponsorship, has increased perception of the good will of the sponsor, show more brand preference and a greater intent to purchase.

As it has been demonstrated since involvement has a positive effect on attitudes, the process of transfer of image and the fit between the event and the sponsor (Olson, 2010; Mazodier and Quester, 2014). Gwinner and Eaton (1999) defined the fit between sponsor and event like the consistency between the image of the event and the brand image. For Olson (2010, p. 16) "these results suggest highly devoting fan/supports of an object are likely to be favorably disposed towards seeing the 'fit' between the object and its sponsors." Similarly, Mazodier and Quester (2014), demonstrated that the event involvement relates positively to the change in the perceived fit for the event and sponsor 
For all these reasons previously raised the following assumptions:

All these authors: Bloom, (1981); Bloch and Brian (1983); Homer and Kahle (1988); Ashforth and Mael, (1989); Branscombe and Wann (1991); Schiffman and Kanuk (1991); Lovelock et al. (1998); Miloch and Lambrecht (2006); Dees et al. (2008); involvement, were more likely to buy products from the sponsor.

H1: Consumers who possess a greater involvement in the event will be more likely to purchase the sponsor brand, than those who do not possess it. .

Then, based on the above by Meenaghan (2001), Dees et al. (2008), Grohs and Reisinger (2014) and Smith and Stewart (2015), propose the second hypothesis related to the involvement of the consumer with the sponsored activity, and the perception of good will or effect halo in the sponsorship of the sponsors.

H2: Most involved consumers with sponsored activity will have a greater perception of good will than fewer involved consumers.

As argue Olson (2010), Mazodier and Quester (2014), showed that after that, involvement affects the congruence between the sponsor-event.

H3: Most involved consumers will perceive a greater fit between the event and sponsor to those less involved consumers.

For Bennet et al (2005), involvement with sport or event can influence the behavior as a spectator of the event taking him to one greater exposure, so propose the following hypothesis:

H4: Most involved consumers with the event will have greater exposure in the event; consumers are not so involved.

Below figure 1 shows the model where the different hypotheses proposed are collected

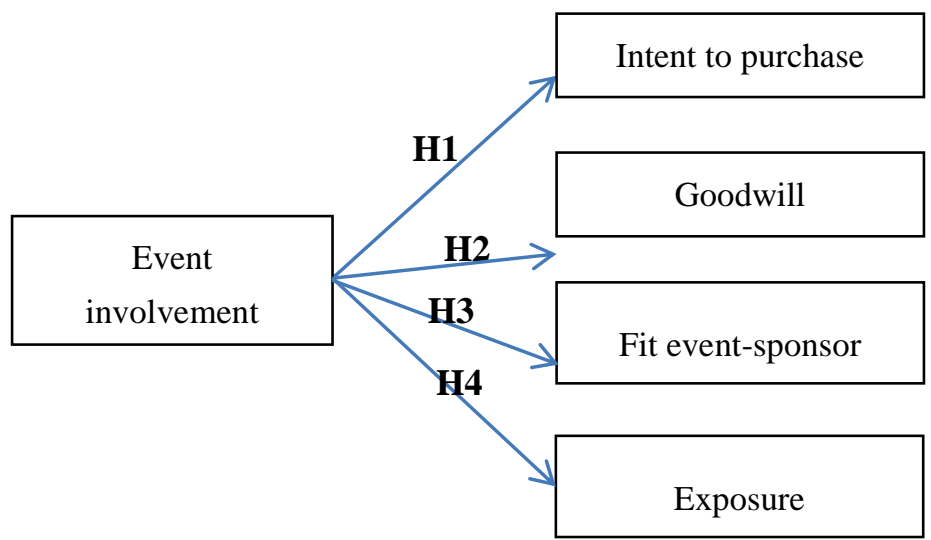

Source: Own elaboration

Figure 1. Proposed model

\section{Methodology}

\subsection{Select of Sporting Activity}

To conduct this research, have chosen the 2016 Rio Olympic Games. The choice for this event as part of our study is justified for the following reasons:

First, few studies have used the Olympic as an event to conduct their research (Quester \& Farrely, 1998; Verity, 2002). It should choose an event had a large number of sponsoring brands, and the Olympics. First, few studies have used the Olympic as an event to conduct their research (Quester \& Farrely, 1998; Verity, 2002). It should choose an event had a large number of sponsoring brands, and the Olympics have 49 marks collecting all types of sponsors ${ }^{3}$. Another reason is

3 Los esponsores Top, Esponsores oficiales y proveedores oficiales. International Olympic Committee Marketing Report-Río 2016 (The Top sponsors, official sponsors and official suppliers. International Olympic Committee Marketing Report-Rio 2016) recovered of: http://touchline.digipage.net/iocmarketing/reportrio2016/94-1 (accessed 2 Jun 2017). 
the audience data, in this case a potential audience of more than 5 billion people, according to the International Olympic Committee (IOC). In addition, the Forbes magazine was valued at 348 billion dollars, behind the Super Bowl which stands in Head of the ranking of sports with 580 million dollars ${ }^{4}$. And finally, different sports activities that are performed within the Olympic Games displayed the logo of the diverse sponsors that appear on the screen during the broadcast, simultaneously to the images of the competition (Lardinoit and Derbaix, 2001), giving sponsors a great visibility.

\subsection{Questionnaire}

To elaborate the questionnaire different scales were used previously developed by other researchers. The majority items have been used a 7-point Likert-type scale, since it is the most widely used in the social sciences (DeSarbo \& Harsman, 1985; Johar \& Pham, and 1999; Gwinner \& Swanson, 2003; Carrillat, Lafferty \& Harris, 2005 and Carrillat, Harris \& Lafferty (2010)... In addition, this type of scale according to Thwaites (1999), gives a fairly high discrimination, and a far more reliable than the 5-point scale.

Used for measure the level of involvement in the event, used battery three questions with a seven-point developed per Gwinner and Swanson (2003) to describe the interest to the event.

The perception of goodwill on the sponsors, based on Stipp and Schiavone (1996) was measured through a set of five questions with seven points.

As for the perception of the fit between the event and sponsor, was using the work done per Gwinner and Eaton (2003), with six questions with a seven-point: 2 were based on the relationship between functionality, 2 based on the relationship and similarity of image and 2 based on image without likeness of the product in the event.

Exposure to the Olympics was measured by a scale of three questions, proposed by Trail and James (2011), with a seven-point where the respondent answered questions about the screening, monitoring and knowledge of the event in question.

Furthermore, to measure the effectiveness of the sponsorship, we will use the purchase intent. Purchase intent was measured using the battery of questions proposed by Carrillat et al. (2005), with three questions with a seven-point semantic differential.

Nevertheless, last and not least, the demographics of the respondent, sex, age, place of residence, income level, educational level and employment status.

\subsection{Analysis and Results}

Object of study constitutes the population Spanish viewers over the age of 18 years of the Rio 2016 Olympic Games. In sense, the total population will be 38.124 .396 individuals from the sampling frame. (INE, 2008) ${ }^{5}$.

The data were collected through a self-administered questionnaire hosted on a platform online Google Drive and disseminated through social networks (Facebook, LinkedIn) during the months of November and December 2017, through a sampling non-probability, sampling ball of snow (Goodman, 1961), in such a way that it could reach a larger number of participating objects of study. This sampling has its advantages but is not exempt of disadvantages (Trespalacios, Vázquez \& Bello, 2005). According to Pan (2010) online surveys have more advantages than the traditional ones since being faster, economic, easy-to-complete, interactive, and are also automatically recorded accurately. However, in addition, they have some drawbacks, such as the low rate of response. For some authors the benefits that such surveys are superior to the disadvantages (Hung \& Law, 2011; Campón, Hernández \& Baptista, 2014). To be spread by email and social networks gave us access to a larger sample and with different demographic characteristics.

The final sample, once removed the invalid questionnaires, was 422. In the context of this sample and setting a level of confidence of the $95 \%(z=1,96)$, with a maximum percentage of imprecision of $5 \%$ on a scale from 1 to 7 and in the worst case, of the variance over the range on the scale, the maximum absolute error of estimate built on base 0.146 would be a factor of accuracy of the scale of the study variables. In table 1 it can be seen the technical details about the research.

\footnotetext{
4 Juegos Olímpicos de Río 2016: ¿cuánto cuestan, cuánto aportan y qué deportistas son los más ricos? (Rio 2016 Olympic Games: how much cost, how much they contribute and what athletes are the richest?), recovered of: http://www.sinembargo.mx/05-08-2016/3076397 (accessed 10 Feb 2018).

5 Estadística del Padrón Continuo a 1 de enero de 2008. Fuente INE.
} 
Table 1. Technical details of research

\begin{tabular}{l|c}
\hline Scope & National \\
\hline Population & Convenience \\
\hline Type of sampling & Questionnaire self-administered online \\
\hline Mode of data collection & 422 \\
\hline Final sample size & $2,434 \%$ \\
\hline $\begin{array}{l}\text { Maximum estimates imprecision (FIEM) } \\
\text { measurement scale (1-5)* }\end{array}$ & 0,146 \\
\hline Absolute error of estimation & December 2017 \\
\hline Realization date & \multicolumn{1}{c}{ S } \\
\hline
\end{tabular}

* Tool for evaluating the degree of imprecision of estimates of average values (Martínez and Martínez, 2008).

Source: Own elaboration.

In relation with the age of the respondent data, the interval in which the greater part of the sample is concentrated between 17 and 27 years, which include $52.6 \%$ for men and $46.9 \%$ for women. For that reason, the sample is not homogeneous in terms of age. Anyhow, this data is interesting since the data obtained ${ }^{6}$, the audiences, both supporters and those who come to the Olympic between 25 and 29 years, with a $19.6 \%$ as of which they do through mobile devices with an age between 18 and 24 and old between 25 to 34 make it both with $35 \%{ }^{7}$, being these intervals of ages where are located on the sample. In terms of data related to sex, there is almost a parity between them, with $48.5 \%$ men and women with 51,42\%.

The statistical packages used during the analysis are the Spss 15.0. and Smart PLS 3.2.7.

To study the reliability of the scales developed for each factor has been used the Cronbach alpha and item-total correlation coefficient. The obtained coefficients are extreme values from 0,824 and 0.964 , so are within acceptable levels of reliability (Nunnally, 1978; Hair, Anderson, Tatham, \& Black, 1999). On the other hand, the item-total correlations were in all cases greater than 0.3 (between ,708 and ,928) (minimum acceptable by Neurosis, 1993). The load factor was significant for all cases exceed the acceptable minimum of 0.5 (, 913 is the minimum value) (Hair et al., 1999).

For the $\mathrm{H} 1$ that proposes that those consumers with one higher level of involvement in the event will have a higher intention to purchase than those less involvement consumers. Through an analysis, ANOVA contrasts the hypothesis, the results presented in Table 2. The high exposure group obtains a stronger mean than individuals with low involvement, a statistically significant difference. These results show that the statistic of Levene is $\mathrm{p} \geq 0.05(, 127)$, with a level of significance of, $000(\mathrm{p} \leq 0.05)$, by which it can be concluded that a greater level of involvement generates higher purchase intention, accepting the $\mathrm{H} 1$.

Table 2. ANOVA Level of involvement-Purchase intention

\begin{tabular}{|c|c|c|c|c|}
\hline \multirow{2}{*}{ Descriptive } & \multicolumn{4}{|c|}{ Purchase intention } \\
\hline & $\mathbf{N}$ & \multicolumn{2}{|c|}{ Media } & SD \\
\hline Low involvement & 220 & \multicolumn{2}{|c|}{3,90} & 1,137 \\
\hline High involvement & 201 & \multicolumn{2}{|c|}{5,51} & 831 \\
\hline \multirow{2}{*}{$\begin{array}{l}\text { Homogeneity of } \\
\text { variances }\end{array}$} & Levene S. & gl.1 & gl.2 & Sig. \\
\hline & 2,343 & 1 & 419 &, 127 \\
\hline ANOVA & $\begin{array}{l}\text { Sum of } \\
\text { squares }\end{array}$ & \multicolumn{2}{|c|}{$\mathbf{F}$} & Sig. \\
\hline Intergroups & 269,863 & \multicolumn{2}{|c|}{268,441} &, 000 \\
\hline
\end{tabular}

Source: Own elaboration

\footnotetext{
${ }^{6}$ Recovered of : https://www.hosteltur.com/117770_perfil-visitante-juegos-olimpicos-rio-janeiro.html

${ }^{7}$ Recovered of :

http://www.yucatanalinstante.com/55-millones-de-telefonos-moviles-se-usaron-en-al-para-ver-los-juegos-olimpicos/
} 
In table 3 it can be seen the ANOVA results made to contrast the hypothesis $\mathrm{H} 2$, where most implicated consumers with sponsored activity will have a greater perception of goodwill than fewer involved consumers. There are significant differences between the averages of the group low involvement score and high involvement score. The result of the statistic of Levene is $p \geq 0.05(, 127)$, with a level of significance of ,000 $(p \leq 0.05)$ so it can assume that the variances are homogeneous, and therefore, it is accepted $\mathrm{H} 2$.

Table 3. ANOVA Level of involvement-Goodwill

\begin{tabular}{l|c|c|c|c}
\hline \multirow{2}{*}{ Descriptive } & \multicolumn{4}{|c}{ Goodwill } \\
\cline { 2 - 5 } & $\mathbf{N}$ & \multicolumn{1}{|c}{ Media } & SD. \\
\hline Low involvement & 220 & \multicolumn{2}{|c}{3,797} & 1,350 \\
\hline High involvement & 201 & \multicolumn{2}{|c}{5,313} & 1,307 \\
\hline $\begin{array}{l}\text { Homogeneity of } \\
\text { variances }\end{array}$ & Levene S. & gl.1 & gl.2 & Sig. \\
\cline { 2 - 5 } \multicolumn{1}{c|}{ ANOVA } & $\begin{array}{l}\text { Sum of } \\
\text { squares }\end{array}$ & \multicolumn{2}{|c}{ F } & Sig. \\
\hline Intergroups & 241,305 & 136,446 &, 000 \\
\hline
\end{tabular}

Source: Own elaboration

Used for the hypothesis H3: most implicated consumers will perceive greater fit between the event and sponsor than the less involved consumers. On Table 4 results from the ANOVA, note that is differences between the averages of the group with a high involvement score was significance that the group with a low involvement score. The static result of Levene is $\mathrm{p} \geq 0.05$ (,952), assume homogeneous variances in both groups, the significance of, 000 worth $(\mathrm{p} \leq, 05)$ and therefore, there is a significant influence of the level of involvement on the perception of fit between the sponsor and the event.

Table 4. ANOVA Level of involvement-Fit event-sponsor

\begin{tabular}{|c|c|c|c|c|}
\hline \multirow{2}{*}{ Descriptive } & \multicolumn{4}{|c|}{ Fit event-sponsor } \\
\hline & $\mathbf{N}$ & \multicolumn{2}{|c|}{ Media } & SD. \\
\hline Low involvement & 220 & \multicolumn{2}{|c|}{4,025} & 1,297 \\
\hline High involvement & 201 & \multicolumn{2}{|c|}{5,437} & 1,290 \\
\hline \multirow{2}{*}{$\begin{array}{l}\text { Homogeneity of } \\
\text { variances }\end{array}$} & Levene S. & gl.1 & gl.2 & Sig. \\
\hline & ,004 & 1 & 419 & ,952 \\
\hline ANOVA & $\begin{array}{l}\text { Sum of } \\
\text { squares }\end{array}$ & \multicolumn{2}{|c|}{$\mathbf{F}$} & Sig. \\
\hline Intergroups & 209,655 & \multicolumn{2}{|c|}{125,210} & ,000 \\
\hline
\end{tabular}

Source: Own elaboration

Finally, the $\mathrm{H} 4$ hypothesis: those most involved consumers in the event will have one exposure greater than this, than those who are not so involved. As displayed in table 5, the results of the ANOVA showed that note results in terms of the averages are higher among the group of high involvement. The result of the statistic of Levene is $p \geq 0.05(, 093)$, so there is homogeneity of variances between the groups. Significance is also additionally $p \leq, 05$, therefore, accepted the hypothesis $\mathrm{H} 4$. 
Table 5. ANOVA Level of involvement-Exposure

\begin{tabular}{|c|c|c|c|c|}
\hline \multirow{2}{*}{ Descriptive } & \multicolumn{4}{|c|}{ Exposure } \\
\hline & $\mathbf{N}$ & \multicolumn{2}{|c|}{ Media } & SD. \\
\hline Low involvement & 220 & \multicolumn{2}{|c|}{3,79} & 1,107 \\
\hline High involvement & 201 & \multicolumn{2}{|c|}{5,48} & ,949 \\
\hline \multirow{2}{*}{$\begin{array}{l}\text { Homogeneity of } \\
\text { variances }\end{array}$} & $\begin{array}{c}\text { Levene } \\
\text { S. }\end{array}$ & gl.1 & gl.2 & Sig. \\
\hline & 2,834 & 1 & 419 & ,093 \\
\hline ANOVA & $\begin{array}{c}\text { Sum of } \\
\text { squares }\end{array}$ & \multicolumn{2}{|c|}{$\mathbf{F}$} & Sig. \\
\hline Intergroups & 300,588 & \multicolumn{2}{|c|}{280,773} & ,000 \\
\hline
\end{tabular}

Source: Own elaboration.

After realized the analysis's ANOVA the adjustment to the model is going to be verified across the structural equations. The method of analysis chosen for this research is Partial Least Square (PLS). It is a modeling method of structural equations with SmartPLS (Ringle, Wende \& Will, 2005). PLS be essentially a regression analysis (Hair, Ringle, \& Sarstedt, 2011), appropriate when examining a series of constructs and their relations with dependent variables and each other (Chin, 1998a).

Conduct a comprehensive evaluation of the results of the structural model follow Hair, Ringle \& Sarstedt, (2013) that propose five measurement criteria significance for the $\beta$ coefficients, 2) coefficient of determination R2, 3) size of the relationships introduced on the F2 model, 4) Stone Geisser (Q2) and 5) SRMR Standardized Root Mean Square. In table 2 refers to the results of the coefficients ( $\beta$ ), to perform these analyses use blindfolding; follow Hair et al. (2013) Q2 $>0$ is indicative of predictive relevance.

According to Chin (1998b), the coefficient should have a positive value. Q2: 0.02, 0.15, 0.35 for the week, moderate, strong degree of predictive relevance of each effect (Hair et al., 2013.). All the values are greater than 0 and therefore, have relevance prognostic being stronger values in the prediction about the fit $(0.476)$ and exposure $(0,419)$.

For the diagnosis at the level of significance of the path coefficients are used again the bootstrap algorithm. According to Hair et al. (2011) and Henseler, Ringle \& Sinkovics (2009) critical values of T are: a test of two-tailed 1.65 (level of significance $=0.10$ or $10 \%), 1.96$ (significance level $=0.05$ or $5 \%$ ) and 2.58 (level of significance $=0.01$ or $1 \%)$. Table 6 shows the values of $T$ for model structural and unless the value of Fit event-sponsor $T=1,316$ and is not significance because $p>0,0$. The rests on the values are significant into the minus 0.02 or $98 \%$.

Table 6. Magnitude and significance of the coefficients $(\beta)$

\begin{tabular}{l|c|c|c}
\hline Hypothesis & Stone Geisser $\mathbf{Q}^{\mathbf{2}^{*}}$ & $\mathbf{t}$ & $\mathbf{p}$ \\
\hline H1: involvement $\rightarrow$ intention to purchase & 0.198 & 10,668 & 0,000 \\
\hline H2: involvement $\rightarrow$ fit & 0.476 & 1,314 & 0,189 \\
\hline H3: involvement $\rightarrow$ goodwill & 0.128 & 7,779 & 0,000 \\
\hline H4: involvement $\rightarrow$ exposure & 0.419 & 3,136 & 0.002 \\
\hline
\end{tabular}

Source: Own elaboration

The measurements of R2 and the level of significance of the path coefficients under which prediction of PLS-SEM aims to explain the variance of the endogenous variables. It is necessary that the values of R2 of the key constructs are high; Values R2 of $0.75,0.5$ or 0.25 for endogenous latent variables in the structural model are considered substantial, moderate or weak respectively (Hair et al., 2011). The examination of the R2 results evaluate them for purchase intent $\mathrm{R} 2=0.24$ and the perception of goodwill R2 $=0.24$, for these two values, the effect is weak.

Thus, the model has predictive relevance for exposition $(\mathrm{R} 2=0,517)$ and fit $(\mathrm{R} 2=0,543)$ the effect is moderate. (see table 7 and figure 2). To analyse the size of relations introduced in the F2 model, follow the indications given by Hair et al. (2013) where the effect sizes F2 (e.g., 0.02, 0.15, 0.35 for weak, moderate, strong effects). Observing the results in table 7, all the effects are strong except for the perception of goodwill $(0,325)$ which is moderate. 
Finally, the last criterion Standardized Root Mean Square Residual (SRMR) measuring the fit of the model. A recent simulation study shows that even entirely correctly specified model can yield SRMR values of 0.06 and higher (Henseler, Dijkstra, SarstedtRingle, Diamantopoulos, Straub, Ketchen, Hair, Hult \& Calantone, 2014.). The value obtained for the $\mathrm{SRMR}=0,068$ so the model fit is good. In the figure 2 are the results of PLS algorithm of the proposed model. .

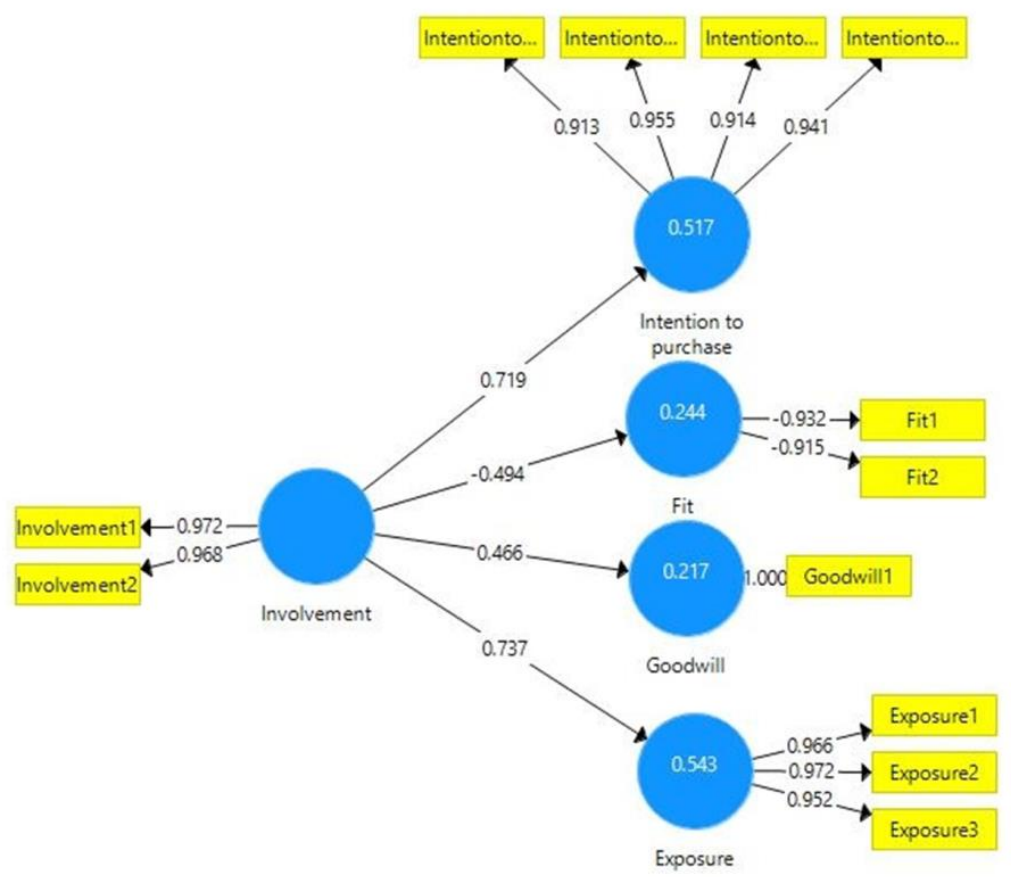

Figure 2. Results of PLS algorithm

Table 7. Summary values $\mathrm{R}^{2}$ and $\mathrm{F}^{2}$

\begin{tabular}{l|l|l}
\hline Hypothesis & $\mathbf{R}^{\mathbf{2}}$ & $\mathbf{F}^{\mathbf{2}}$ \\
\hline H1: involvement $\rightarrow$ intention to purchase & 0,244 & 1,190 \\
\hline H2: involvement $\rightarrow$ fit & 0,543 & 0,322 \\
\hline H3: involvement $\rightarrow$ goodwill & 0,245 & 0.325 \\
\hline H4: involvement $\rightarrow$ expoure & 0,517 & 1,990 \\
\hline
\end{tabular}

Source: Own elaboration

\section{Conclusions, Limitations of the Study and Future Research Lines}

Then, the conclusions that derive from the research carried out will be developed.

First, one of the factors that have been investigated, and found directly affects the economic benefits for the enterprise: purchase intent and its relationship with the level of involvement. This influence was demonstrated Hickman (2015), which in addition to recognize more the sponsor also had a higher purchase intent. Purchase intent is a measure behavioral, that can help us to verify the effectiveness of the sponsorship (Koo, Quarterman \& Flynn, 2006; Yong Jae et al., 2008; Gilaninia \& Abbaszadeh, 2011).

The level of consumer involvement also influences other factors studied in this research, the perception of goodwill, as well as already it was proved by Gross and Reisinger (2014), that consumers most involved in the event had more perceptions of goodwill. This fact implies that the sponsorship has an advantage over other communication tools, since the consumer perceived more positively and therefore, does not create a barrier as in advertising.

On the other hand, the level of involvement in the event also influences the perception of the fit between the sponsor and the event, although Mazodier and Quester (2014), showed that this was happening only when the previous perception of fit was incongruous. The fact that the level of involvement affects the perception of the setting, can make us come at the 
conclusion, that if segment individuals depending on their level of involvement can create sponsorships where it is not necessary to search both the adjustment for the level of consumer involvement.

Finally, is had been demonstrated that those individuals who are more involved in the event tend to expose themselves more to the sponsorship. Thus, holding it Bennet et al. (2009), it is possible that in action sports, the level of involvement can increase their behavior as spectators and as a result are more exposed to the brand promotions. In addition, if there is no exposure to the event not be entered in contact with the sponsorship, and involvement with this, almost the guarantee.

Highlight the results of different analyses with the structural equations (PLS-SEM) show that the endogenous variable that gets lower in the Stone Geisser test as well as the F2 is the perception of good will. The only variable that is not significant over $90 \%$ is the perception of the fit event-sponsor. For the other variables, the results are satisfactory, also earning a strong adjustment in Standardized Root Mean Square Residual. Therefore, confirming the results obtained from the ANOVA test used previously to contrast the hypothesis.

The study limitations are related to the sample, and that although it is heterogeneous, the segments where our sample concentrates are located between 17 and 27 years ${ }^{8}$.

To conclude, a possible future line of research is related to consumers involved in a sport, event or athlete is a very attractive market segment, and could therefore be interesting understand what sports a higher level of involvement of the consumer has, since as we have demonstrated involvement affects the most important to get with all sponsorship objectives. Thus, organizations may choose those sports with a greater involvement level since you would get better results by investing in them.

\section{References}

Alexandris, K., Tsaousi, E., \& James, J. (2007). Predicting sponsorship outcomes from attitudinal constructs: the case of a professional basketball event. Sport Marketing Quarterly, 16(3), 130-9.

Alexandris, K., \& Tsiotsou, R. (2012). Testing a Hierarchy of Effects Model of Sponsorship Effectiveness .Journal of Sport Management, 26, 363-378

Alonso-Dos-Santos, M.; Vveinhardt, J.; Ferran Calabuig-Moreno, F., \& Montoro-Rios, J. (2016). Involvement and Image Transfer in Sports Sponsorship. Inzinerine Ekonomika-Engineering Economics, 27(1), 78-89.

Antil, J. (1984). Conceptualization and operationalization of involvement. In T. G. Kinnear (Ed.), Advances in consumer research, 11, 203-209. Provo, UT: Association for Consumer Research.

Ashforth, B., \& Mael, F. (1989). Social identity theory and the organization. Academy of Management Journal, 14, $20-39$.

Beaton, A. A., Funk, D. C., Ridinger, L., \& Jordan, J. (2011). Sport involvement: A conceptual and empirical analysis. Sport Management Review, 14(2), 126-140. http://dx.doi.org/10.1016/j.smr.2010.07.002

Bennett, G., Ferreira, M., Tsuji, Y., Siders, R., \& Cianfrone, B. (2006). Analyzing the effects of advertising type and antecedents on attitude toward advertising in sport. International Journal of Sports Marketing and Sponsorship. 8(1), $62-81$.

Bennett, G., Ferreira, M., Lee, J., \& Polite, F. (2009). The role of involvement in sports and sport spectatorship in sponsor's brand use: the case of Mountain Dew and action sports sponsorship. Sport Marketing Quarterly, 18, 14-24.

Bloch, P., \& Richins, M. (1983). A theoretical model for the study of product importance perceptions. Journal of Marketing, 47(3), 69-81.

Bloom, P. (1981). What marketers need to know about the marketing of professional services. In J. H. Donnelly \& W. R. George (Eds.), Marketing of services, (86-87). Chicago: American Marketing Association

Branscombe, N., \& Wann, D. (1991). The positive social and self-concept consequences of sports team identification. Journal of Sport and Social Issues, 15, 115-127

Campón Cerro, A. M., Hernández Mogollón, J. M., \& Baptista Alves, H. M. (2014). La lealtad hacia los destinos de turismo rural: un estudio causal de sus determinantes bajo el enfoque transaccional y relacional del marketing (Thesis). Universidad de Extramadura. España.

Carrillat, F; Lafferty, B., \& Harris, E. (2005). Investigating sponsorship effectiveness: Do less familiar brands have an advantage over more familiar brands in single and multiple sponsorship arrangements?. The Journal of Brand Management, 13(1), 50-64.

\footnotetext{
${ }^{8}$ The age range is within the spectators who attend or see the Olympic, as already explaining in the section on analysis and results in paragraph 4 .
} 
Carrillat, F., Harris, E., \& Lafferty, B. (2010). Fortuitous brand image transfer - investigating the side effect of concurrent sponsorships. Journal of Advertising, 39(2), 109-123.

Celsi, R.L. and Olson, J. C. (1988). The Role of Involvement in Attention and Comprehension Processes. Journal of Consumer Research, 15(2), 210-224.

Chaudhuri, A. (2000). A macro analysis of the relationship of product involvement and information search: the role of risk. Journal of Marketing Theory and Practice, 8(1), 1-15.

Chin, W. W. (1998a). Issues and opinion on structural equation modeling. MIS Quarterly, 22(1), 1-10.

Chin, W. W. (1998b). The partial least squares approach to structural equation modeling. In G. A. Marcoulides (Ed.), Modern Methods for Business Research ( 295-336). New Jersey, USA: Lawrence Erlbaum Associates..(Ed.), Modern Methods for Business Research. Erlbaum, Mahwah, 295e358.

Crimmins, J., \& Horn, M. (1996). Sponsorship: from management ego trip to marketing success. Journal of Advertising Research, 36(4), 11-21.

Cubillo Pinilla. J. M., \& Cerviño Fernández, J. (coordinators). (2008). Marketing sectorial. Madrid. ESIC Editorial

D’Astous, A., \& Bitz, P. (1995). Consumer evaluations of sponsorship programmes. European Journal of Marketing, 29(12), 6-22.

Day, E., Royne, M., \& Camacho, A. (1995). Opportunities for involvement research: a scale development approach. Journal of Advertising, 24(3), 69-75.

Dees, W; Bennett, G., \& Villegas, J. (2008). Measuring the Effectiveness of Sponsorship of an Elite Intercollegiate Football Program. Sport Marketing Quarterly, 17, 79-89.

Dees, W., Bennett, G., \& Ferreria, M. (2010). Personality fit in NASCAR: An evaluation of driver-sponsor congruence and its impact on sponsorship effectiveness outcomes. Sport Marketing Quarterly, 18(2), 25-35.

DeSarbo, W. S., \& Harshman, R. A. (1985). Celebrity-brand congruence analysis. Current Issues and Research in Advertising, 1, 17-52.

Divinity (2017). Cuál es la marca de relojes más valiosa del mundo? Recovered of: http://theluxonomist.es/2017/10/04/cual-es-la-marca-de-relojes-mas-valiosa-del-mundo/the-luxonomist(accesed feb 10 2018).

Donovan, D. T.; Carlson, B. D., \& Zimmerman, M. (2005). The influence of personality traits on sports fan identification. Sport Marketing Quarterly, 14(1), 31-42.

Droge, C. (1989). Shaping the route to attitude change: central versus peripheral processing through comparative versus no comparative advertising. Journal of Marketing Research, 26(May), 193-204.

Evrard, Y., \& Aurier, P. (1996). Identification and validation of the components of the person-object relationship. Journal of Business Research, 37, 127-134.

Farrelly, F. J., Quester, P. G. , \& Burton, R. (2006). Changes in sponsorship value: Competencies and capabilities of successful sponsorship relationships. Industrial Marketing Management, 35(8), 1016-1026. http://dx.doi.org/10.1016/j.indmarman.2006.05.006

Filo, K., Funk, D. C., \& O’Brien, D. (2010). The antecedents and outcomes of attachment and sponsor image within charity sport events. Journal of Sport Management, 24, 623-648.

Funk, D., Redinger, L., \& Moorman, A. (2004). Exploring origins of involvement: Understanding the relationship between the consumer motives and involvement with professional sports teams. Leisure Sciences, 26, 35-61.

Gilaninia, S., \& Abbaszadeh, M. H. (2011). Assessing the constructs of sport sponsorship effectiveness and theoretical relationships between them among football fans in Iran. Journal of Basic and Applied Scientific Research, 1(7), 606-616.

Gómez Nieto, B. (2017). Fundamentos de la Publicidad. Editorial ESIC. Madrid

Goodman, Leo, A. (1961). Snowball Sampling. The Annals of Mathematical Statistics, 32(1), 148-170. https://doi.org/10.1214/aoms/1177705148.

Greenwald, A., \& Leavitt, C. (1984). Audience Involvement in Advertising: Four Levels. Journal of Consumer Research, 11(Junio), 581-592.

Greenwood, P., Kanters, M., \& Casper, J. (2006). Sport Fan Team Identification Formation in Mid-Level Professional Sport. European Sport Management Quarterly, 6(3), 253-265. 
Grohs, R., Wagner, U., \& Vsetecka, S. (2004). Assessing the effectiveness of sports sponsorships-An empirical examination. Schmalenbach Business Review, 56(2), 119-138.

Grohs, R., \& Reisinger, H. (2014). Sponsorship effects on brand image: The role of exposure and activity involvement. Journal of Business Research, 67(5), 1018-1025.

Gwinner, K., \& Swanson, S. R. (2003). A model of fan identification: antecedents and sponsorship outcomes. Journal of Services Marketing, 17(3), 275-294.

Gwinner, K., \& K. P. Eaton, J. (1999). Building brand image through event sponsorship: The role of image transfer. Journal of Advertising, 28(4), 47-57.

Hair, J., Anderson, R., Tatham, R., \& Black, W. (1999). Análisis Multivariante. $5^{\text {a }}$ ed. Madrid. Editorial Prentice Hall.

Hair, J. F., Ringle, C. M., \& Sarstedt, M. (2011). PLS-SEM: indeed a silver bullet, Journal of Marketing Theory and Practice, 19(2), 139-151.

Hair,J. F., Ringle, Ch. M., \& Sarstedt, M. (2013). Partial Least Squares Structural Equation Modeling: Rigorous Applications, Better Results and Higher Acceptance, 46(1-2), 1-12.

Havitz, M. E., \& Howard, D. R. (1995) "How Enduring is Enduring Involvement? A Seasonal Examination of Three Recreational Activities". Journal of Consumer Psychology, 4(3), 255-276.

Havitz, M. E., \& Mannell, R. C. (2005). Enduring Involvement, Situational Involvement in Leisure and Non-Leisure Activities. Journal of Leisure Research, 37(2), 152-77.

Henseler, J., Ringle, C. M. \& Sinkovics, R. R., (2009). The use of partial least squares path modeling in international marketing, Advances in International Marketing, 20, 277-320.

Henseler, J., Dijkstra, T. K., Sarstedt, M., Ringle, C. M., Diamantopoulos, A., Straub, D. W., Ketchen, D. J. Jr, Hair, J. F., Hult, G. T. M., \& Calantone, R. J. (2014). Common beliefs and reality about PLS: comments on Rönkkö \& Evermann (2013), Organizational Research Methods, 17(2), 182-209.

Homer, P., \& Kahle, L. (1989). A Structural Equation Test of the Value-Attitude-Behavior Hierarchy. Journal of Personality and Social Psychology, 54(4), 638-646.

Iwasaki, Y., \& Havitz, M. E. (1998). A path analytic model of the relationships between involvement, psychological commitment, and loyalty. Journal of Leisure Research, 30, 256-2

Hickman, Th. M. (2015). The Impact of Fan Identification, Purchase Intentions, and Sponsorship Awareness on Sponsors' Share of Wallet. Sport Marketing Quarterly. 24(3), 170-182.

Huang, M. (2006). Flow, enduring, and situational involvement in the web environment: Atripartite second-order examination. Psychology and Marketing, 23(5), 383-411.

Hung, K., \& Law, R. (2011). An overview of Internet-based surveys in hospitality and tourism journals. Tourism Management, 32(4), 717-724.

Hur, Y., Ko, Y. J., \& Claussen, C. L. (2012). Determinants of using sports web portals: An empirical examination of the sport website acceptance model. International Journal of Sports Marketing \& Sponsorship, 13(3), 169-188.

International Olympic Committee Marketing Report-Río 2016, available at: http://touchline.digipage.net/iocmarketing/reportrio2016/94-1 (Accesed 20 October 2017).

Johar, G. V., \& Pham, T. M., (1999). Relatedness, prominence, and constructive sponsor identification. Journal of Marketing Research, 3(3), 299-313.

Johar, G. V., Pham, M. T., \& Wakefield, K. L. (2006). Howevent sponsors are really identified: A (baseball) field analysis. Journal of Advertising Research, 46(6), 183-198.

Juegos, O. de R. (2016). Cuánto cuestan, cuánto aportan y qué deportistas son los más ricos? (Rio 2016 Olympic Games: how much cost, how much they contribute and what athletes are the richest?), recovered of: http://www.sinembargo.mx/05-08-2016/3076397 (accesed 10 feb 2018)

Kahle, L. R., Kambara, K. M., \& Rose, G. M. (1996). A functional model of fan attendance motivations for college football. Sport Marketing Quarterly, 5(4), 51-60.

Keller, K. L. (1993). Conceptualizing, Measuring, and Managing Customer-Based Brand Equity. Journal of Marketing, $57(1), 1-22$

Keller, K. L., (2003). Conceptualizing, measuring and managing consumer-based brand equity. Journal of Marketing, 57(1), 1-22. 
Ko, Y. J., Kim, Y. K., Kim, M. K., \& Lee, J. H. (2010). The role of involvement and identification on event quality perceptions and satisfaction: A case of US Taekwondo Open. Asia Pacific Journal of Marketing and Logistics, 22(1), $25-39$.

Koo, G. Y., Quarterman, J., \& Flynn, L. (2006). Effect of perceived sport event and sponsor image fit on consumers' cognition, affect, and behavioral intentions. Sport Marketing Quarterly, 15(2).

Küster, I., Vila, N., \& Aldás, J. (2009). Efecto del Patrocinio de la Copa América en las percepciones de Luis Vuitton: una perspectiva internacional. Universia Business Review | Segundo Trimestre.

Lacey, R., Close, A. G., \& Finney, R. Z. (2010). The pivotal roles of product knowledge and corporate social responsibility in event sponsorship effectiveness. Journal of Business Research, 63(11), 1222-1228. http://dx.doi.org/10.1016/j.jbusres.2009.11.001

Lardinoit, T., \& Derbaix, C. (2001). Sponsorship and recall of sponsors. Psychology \& Marketing, 18(2), 167-190.

Lascu, D. N., Giese, T. D., Toolan, C., Guehring, B., \& Mercer, J. (1995). Sport involvement: a relevant individual difference factor in spectator sports. Sport Marketing Quarterly, 4(4), 41-46.

Laurent, G., \& Kapferer, J. (1985). Measuring consumer involvement profiles. Journal of Marketing Research, 22(1), febrero, 41-53.

Laverie, D., \& Arnett, D. (2000). Factors affecting fan attendance: The influence of identity salience and satisfaction. Journal of Leisure Research, 32(2), 225-246.

Levin, A. M.; Joiner, C., \& Cameron, G. (2001). The impact of sports sponsorship on consumer' Brand attitudes and recall: the case of NASCAR fans. Journal of Current Issues and Research in Advertising, 23(2), 23-31.

Lovelock, C, Patterson, P., \& Walker, R. (1998). Services marketing. Sydney, Australia: Prentice Hall.

Maheswaran, D., \& Sternthal, B. (1990).The effects of knowledge, motivation and type of message on ad processing and product judgements. Journal of Consumer Research, 17, 66-73

Martínez, J. A., \& Martínez, L. (2008). Determinación de la máxima varianza para el cálculo del factor de imprecisión sobre la escala de medida, y extensión a diferentes tipos de muestreo. Psicothema, 20(2), 311-316

Mazodier, M., \& Quester, P. (2014). The role of sponsorship fit for changing brand affect: A latent growth modeling approach. International Journal of Research in Marketing, 31(1), 16-29.

Meenaghan, T. (2001). Understanding sponsorship effects. Psychology \& Marketing, 18(2), 95-122.

Miloch, K. S., \& Lambrecht, K.W. (2006). Consumer Awareness of Sponsorship at Grassroots Sport Events. Sport Marketing Quarterly, 15, 147-154,

Mittal, B. (1989). A theoretical analysis of two recent measures of involvement. Advances in consumer research, vol. 16, editado por T.K. Srull, Provo (UT), Association for consumer research, 697-702.

Nicholls, J. A. F., Roslow, S., \& Dublish, S. (1999). Brand recall and brand preference at sponsored golf and tennis tournaments. European Journal of Marketing, 33(3/4), 366-386.

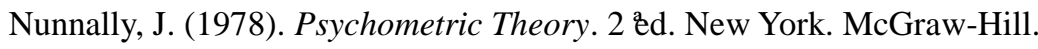

Nurosis, M. (1993). Spss. Statistical data analysis. Ed. SPSS Inc.

Olson, E. L., \& Thjømøe, H. M. (2003). The effects of peripheral exposure to information on brand preference. European Journal of Marketing, 37 Iss: 1/2, 243-255. http://dx.doi.org/10.1108/03090560310453280

Olson, E. L., \& Thjømøe, H. M. (2009). Sponsorship effect metric: assessing the financial value of sponsoring by comparisons to television advertising. Journal of The Academy of Marketing Science, 37(4), 504-515. https://doi.org/10.1007/s11747-009-0147-z.

Olson, E. (2010). "Does sponsorship work in the same way in different sponsorship contexts?. European Journal of Marketing, 44(1/2), 180 -199.

Pan, B. (2010). Online travel surveys and response patterns. Journal of Travel Research, 49(1), 121-135.

Pérez, C. (2006). La implicación del consumidor en la adquisición de bienes y servicios. Revista ESIC Market, №. 123, 93-113

Pham, T. (1991). The evaluation of sponsorship effectiveness: a model and some methodological consideration, Gestión 2000, 4. available at: http://www.columbia.edu/ tdp4/G2000-1991.pdf (accesed 13 January 2018)

Peter, J. P., \& Jerry, C. O. (1987), Consumer Behavior: Marketing Strategy Perspectives, Homewood, IL: Irwin 
Quester, P., \& Farrelly, F. (1998). Brand association and memory decay effects of sponsorship: the case of the Australian Formula One Grand Prix. Journal of Product \& Brand Management, 7( 6), 539-556.

Quester, P., \& Thompson, B. (2001). Advertising and promotion leverage on arts sponsorship effectiveness. Journal of Advertising Research, 41(1), 33-47

Ringle, C. M., Wende, S., \& Will, A. (2005). SmartPLS (Version 2.0). Hamburg: University of Hamburg.

Rothschild, M. L. (1984). Perspectives on Involvement: Current Problems and Future Directions, Advances in Consumer Research, 11, 216-217.

Roy, D. (2011). Impact of congruence in cause marketing campaigns for professional sport organisations. International Journal of Sport Management and Marketing. 10(1-2), 21-34.

Sandler, D. M., \& Shani, D. (1993). The Value of Sponsorship in Sports Marketing: An Empirical Study. Proceedings of the 1992 Conference of the American Academy of Advertising. Edited by: Reid, Leonard N. 82-83. Athens, GA: The University of Georgia.

Sandler, D., \& Shani, D. (1993). Sponsorship and Olympic Games: the consumer perspective. Sport Marketing Quarterly, 2(3), 38-43.

Sandler, D. M., \& Shani, D. (1989). Olympic sponsorship vs. "ambush" marketing: Whogets the gold?. Journal of Advertising Research, 29(august/September), 9-14.

Sherif, M., \& Cantril, H. (1947). The psychology of ego-involvement. New York: John Wiley \& Sons, Inc

Schiffman, L.G., \& Kanuk, L. L. (1991). Consumer behavior. Prentice-Hall International, Business \& Economics - 680 pages.

Smith, A., \& Stewart, B. (2015). Introduction to port marketing. New York. Routledge.

Spanish.xinhuanet.comRío (2016). Río 2016: Cifras sobre Juegos Olímpicos. Avaliable at: http://spanish.xinhuanet.com/2016-08/02/c_135555966.htm (accesed 2 December 2017)

Stevens, S., \& Rosenberger, P. J. (2012). The influence of involvement, following sport and fan identification on fan loyalty: An Australian perspective. International Journal of Sports Marketing \& Sponsorship, 13(3), 220-234.

Stone, R. N. (1984). The Marketing Characteristics of Involvement. in NA - Advances in Consumer Research Volume 11, eds. Thomas C. Kinnear, Provo, UT: Association for Consumer Research, 210-215.

Speed, R., \& Thompson, P. (2000). Determinants of sports sponsorship response. Journal of the Academy of Marketing Science, 28(2), 226-238.

Stipp, H., \& Schiavone, N. P. (1996). Modeling the impact of Olympic sponsorship on corporate image. Journal of Advertising Research, 36(4), 22-28.

Trail, G. T., \& James, J. D. (2011). Theories of consumer behavior. In sport consumer behavior: A model of sport spectator conative loyalty. Sport marketing quartely, 14(2), 98-112.

Trespalacios, J. A., Vázquez, R., \& Bello, L. (2005), Investigación de Mercados, Thomson, Madrid.

Turco, D. (1995). The influence of sponsorship on product recall and image among sport spectator. In world marketing congress proceedings. Academy of Marketing Science, 7(3), 116-110.

Thwaites. (1999). "Closing the gaps: service quality in sport tourism", Journal of Services Marketing, 13(6), 500-516. https://doi.org/10.1108/08876049910298766

Verity, J. (2002). Maximizing the marketing potential of sponsorship for global brands. European Business Journal, 14(4), 161-173.

Wolfsteiner, E., Grohs, R., \& Wagner, U. (2015). What drives ambush marketer misidentication? Journal of Sport Management, 15(4), 367-383.

Wong, K. K. K. (2013). Partial least squares structural equation modeling (PLS-SEM) techniques using SmartPLS. Marketing Bulletin, 24(1), 1-32.

Yong Jae, K., Kyoungtae, K., Cathryn L, C., \& Tae Hee, K. (2008). The effects of sport involvement, sponsor awareness and corporate image on intention to purchase sponsors' products. International Journal of Sports Marketing \& Sponsorship, January 01.

Zaichkowsky, J. (1985). Measuring the involvement construct. Journal of Consumer Research, 12, 341-352. 


\section{Copyrights}

Copyright for this article is retained by the author(s), with first publication rights granted to the journal.

This is an open-access article distributed under the terms and conditions of the Creative Commons Attribution license (http://creativecommons.org/licenses/by/4.0/). 